\title{
EFFECT ON THE OFFSPRING OF REPEATED CAFFEINE ADMINISTRATION TO PREGNANT RATS
}

\author{
ENID F. GILBERT AND W. R. PISTEY \\ Departments of Pathology, University of Wisconsin School of Medicine, \\ Madison, Wisconsin 53706, and University of West Virginia, Morgantown, \\ West Virginia 26506, U.S.A.
}

(Received 21st August 1972)

\begin{abstract}
Summary. Repeated intraperitoneal injections of caffeine given to rats in dosages ranging from 4 to $16 \mathrm{mg}$ daily throughout pregnancy resulted in significant resorptions and decrease in the birth weight of the offspring. These effects were dose-related. Developmental malformations, however, were not observed in the offspring at these dosage levels.

These results indicate that caffeine, even in low doses which at the lower levels of the experiment may approximate to the daily human intake of a heavy coffee consumer, suppresses growth of embryonic and fetal tissues.
\end{abstract}

\section{INTRODUCTION}

Since caffeine is a universal beverage and is consumed in large quantities by the human race, its effect during gestation on the developing offspring is important. There is good evidence that caffeine is mutagenic in bacteria (Demerec and his co-authors, 1950; Demerec, Bertani \& Flint, 1951; Gezelius \& Fries, 1952; Novick, 1955; Greer, 1968), fungi (Fries, 1950; Zetterberg, 1959) and plants (Kihlman \& Levan, 1949; Kihlman, 1952), as well as in Drosophila (Andrew, 1959; Ostertag, 1963; Ostertag \& Haake, 1966; Mittler, Mittler \& Owens, 1967) and in human cells in vitro (Ostertag, Duisberg \& Stürmann, 1965; Ostertag, 1966a, b; Ostertag \& Greif, 1967). Although there have been some conflicting reports on the mutagenicity of caffeine in higher organisms (Adler, 1970; Epstcin, 1970), chromosomal breakage has been induced in human cell cultures as well as in Drosophila (Kuhlmann, Fromme, Heege \& Ostertag, 1968).

Caffeine has been proven to be teratogenic in the offspring of mice following a single large intraperitoneal injection (Nishimura \& Nakai, 1960; Fujii \& Nishimura, 1969), but the effect of relatively low doses has not been studied. In the present paper, the effect of repeated caffeine injections on the offspring of pregnant rats given a dose approximating to that of a high daily coffee consumption of humans is examined. 


\section{MATERIALS AND METHODS}

Forty female Holzer rats, each weighing approximately $200 \mathrm{~g}$, were mated. Following observation of spermatozoa in the vaginal smears, each rat was given intraperitoneal injections of caffeine at 6-hr intervals. Taking the figure of 100 $\mathrm{mg}$ caffeine in an average cup of coffee, the daily equivalents per $50 \mathrm{~kg}$ (the average weight of an adult human female) were calculated from the dosage schedule shown in Table 1.

Table 1. Dosage schedule of caffeine given to mated female rats

\begin{tabular}{l|c|c|c}
\hline \multicolumn{1}{c|}{ Group* } & Caffeine† & Total daily dose & $\begin{array}{c}\text { Daily caffeine } \\
\text { equivalent as } \\
\text { coffee/50 kg }\end{array}$ \\
\hline A & $1 \mathrm{mg}$ & $4 \mathrm{mg}$ & 10 cups \\
B & $2 \mathrm{mg}$ & $8 \mathrm{mg}$ & 20 cups \\
C (control) & $4 \mathrm{mg}$ & $16 \mathrm{mg}$ & 40 cups \\
D (c) & - & - \\
\hline
\end{tabular}

\footnotetext{
* Each group contained ten rats.

† Given intraperitoneally every $6 \mathrm{hr}$; the control group received $1 \mathrm{ml}$ normal saline intraperitoneally every $6 \mathrm{hr}$.
}

The dosage was continued from Day 0 to Day 20, at which time all animals were killed. Random serum caffeine levels were determined by the method of Axelrod \& Reichenthal (1953) in each group. The peak of caffeine concentration occurred $30 \mathrm{~min}$ after caffeine injection. The highest serum levels of caffeine reached in the experimental groups were: Group A, $2.8 \mathrm{mg} / 100 \mathrm{ml}$; Group B, $6.6 \mathrm{mg} / 100 \mathrm{ml}$; Group C, $14.6 \mathrm{mg} / 100 \mathrm{ml}$.

The litter size, number of resorptions, fetal weights and placental weights were determined. The fetuses were fixed in $10 \%$ buffered formalin and examined for anomalies. Attempts to identify skeletal malformations were made by staining in alizarine- $\mathrm{KOH}$ and clearing soft tissues in glycerol.

\section{RESULTS}

Table 2 summarizes the average litter size, number of resorptions, fetal weight and placental weight in each group. A $20 \%$ decrease in litter size was observed in Group A given $4 \mathrm{mg}$ caffeine/day and $40 \%$ decrease in Groups B and C.

Table 2. Effects of caffeine administration on the offspring of pregnant rats

\begin{tabular}{c|c|c|c|c|c}
\hline Group & $\begin{array}{c}\text { Daily } \\
\text { dose of } \\
\text { caffeine }(\mathrm{mg})\end{array}$ & $\begin{array}{c}\text { Average } \\
\text { litter } \\
\text { size }\end{array}$ & $\begin{array}{c}\text { Average } \\
\text { no. of } \\
\text { resorptions }\end{array}$ & $\begin{array}{c}\text { Average } \\
\text { fetal } \\
\text { weight }(\mathrm{g})\end{array}$ & $\begin{array}{c}\text { Average } \\
\text { placental } \\
\text { weight }(\mathrm{g})\end{array}$ \\
\hline $\mathrm{A}$ & 4 & 8 & $2 \cdot 1$ & $4 \cdot 20$ & $0 \cdot 6$ \\
$\mathrm{~B}$ & 8 & 6 & $4 \cdot 0$ & $3 \cdot 50$ & $0 \cdot 5$ \\
$\mathrm{G}$ & 16 & 6 & $4 \cdot 0$ & $3 \cdot 20$ & $0 \cdot 4$ \\
$\mathrm{D}$ & Control & 10 & $1 \cdot 2$ & $4 \cdot 60$ & $0 \cdot 7$ \\
\hline
\end{tabular}


Likewise, the average number of resorptions was twice as great in Group A (4 mg caffeine/day) as compared with the control group, and was quadrupled in Groups B and C.

The average fetal weight was significantly decreased in all experimental groups, the decrease appearing to be dose-related. The placental weight generally corresponded to the weight of the fetus and the placentae showed no significant gross or histological changes.

No significant developmental malformations or skeletal defects were observed in the fetuses after dissection and staining.

\section{DISGUSSION}

Caffeine is a purine-1,3,7-trimethyl xanthine. It has been observed recently that inhibition of DNA polymerase activity is effected in human cell cultures at concentrations of caffeine above $500 \mu \mathrm{g} / \mathrm{ml}$ after $48 \mathrm{hr}$ (Wragg, Carr \& Ross, 1967). When $1 \%$ caffeine is added to Hela cell cultures, extensive changes in the fine structure of the cells occurs with expulsion of nuclear material into the cytoplasm (Ostertag \& Fromme, 1967). In addition, breakage has been reported in human chromosomes, even in doses below $500 \mu \mathrm{g} / \mathrm{ml}$ (Kuhlmann et al., 1968).

More recently, a high frequency of chromatid aberrations, predominantly of the unstable type, has been induced with caffeine in human leucocytes and human embryonic cells in culture (Lee, 1971). Studies on the fate of radiationinduced chromosome aberrations (Buckton, Jacobs, Court Brown \& Doll, 1962; Norman, Sasaki, Ottoman \& Fingerhut, 1966; Sasaki \& Norman, 1967; Leonard, 1970) have shown that such unstable aberrations do not survive cell divisions due to the genetic imbalance caused by the abnormal distribution of genetic material to the daughter cells. Furthermore, the absence of exchange aberrations and the restriction of damage to the DNA synthesis phase which Lee (1971) observed may relate to the ambiguous results on the effectiveness of caffeine in the induction of dominant lethal mutations in higher organisms.

A change in sex ratio has been observed in female larvae of Drosophila exposed to $1 \%$ caffeine for $1 \mathrm{hr}$ (Zetterberg, 1959). After hatching, there was a shift of sex ratio in favour of females. Previous investigators have shown for X-rays (Oster, 1958; Ostertag \& Muller, 1959; Ostertag, 1963) as well as for chemical mutagens (Ostertag, 1963) that this is related to genetic damage induced by chromosomal breakage. Loss of the $\mathrm{X}$ chromosome in male cells is lethal whereas a single $\mathrm{X}$ chromosome loss in female cells can be tolerated.

In the dog, Axelrod \& Reichenthal (1953) have shown that caffeine is distributed freely in the intracellular water of all tissues. Furthermore, Goldstein \& Warren (1962) have demonstrated that caffeine administered to the human adult gains access to the gonads and fetal tissues and reaches concentrations substantially the same as those in the plasma. It can, therefore, be concluded that the consumption of coffee several times daily by the human pregnant female allows constant exposure of the fetal tissues to the effects of the caffeine. Fetal gonadal tissue is also exposed, with the potential hazard of a deleterious effect on the germ cells.

Congenital malformations in the offspring of mice treated with a single large 
(250 $\mathrm{mg} / \mathrm{kg}$ body weight) intraperitoneal injection of caffeine have been observed by Nishimura \& Nakai (1960) and Fujii \& Nishimura (1969). When the compound was administered between the 9 th and 14th days, malformations, predominantly in the skeletal system, were found. Haematomata were also frequently observed.

The present experiments utilizing relatively small dosages of caffeine indicate that although fetal malformations are not produced at this low concentration, there is a significant degree of fetal loss and decrease in birth weight.

\section{ACKNOWLEDGMENT}

This work was supported by a General Institutional Support Grant from the University of Wisconsin School of Medicine.

\section{REFERENCES}

AdLER, I. D. (1970) The problem of caffeine mutagenicity. In: Chemical Mutagenesis in Mammals and Man, p. 383. Eds. F. Vogel and G. Röhrborn. Springer, Berlin.

ANDREw, L. E. (1959) The mutagenic activity of caffeine in Drosophila. Am. Nat. 43, 135.

Axelrod, J. \& Reichenthal, J. (1953) The fate of caffeine in man and a method for its estimation in biological material. J. Pharmac. exp. Ther. 107, 519.

Buckton, K. E., Jacobs, P. A., Court Brown, W. M. \& Doll, R. (1962) A study of the chromosome damage persisting after X-ray therapy for ankylosing spondylitis. Lancet, ii, 676.

Demerec, M., Bertani, G. \& Flint, J. (1951) A survey of chemicals for mutagenic action on $\boldsymbol{E}$. coli. Am. Nat. 85, 119.

Demerec, M., Witkin, E. M., Catlin, B. W., Flint, J., Belser, W. L., Dissosway, G., Kennedy, F. L., Meyer, N. C. \& Schwartz, A. (1950) The gene. Tb. Carnegie Instn Wash. 49, 144.

EPSTEYN, S. (1970) The failure to induce mutagenic effects or to synergize the effects of known mutagens in mice. In: Ghemical Mutagenesis in Mammals and Man, p. 404. Eds. F. Vogel and G. Röhrborn. Springer, Berlin.

FrIes, N. (1950) The production of mutations by caffeine. Hereditas, 36, 134.

FujIr, T. \& Nishimura, H. (1969) Teratogenic actions of some methylated xanthines in mice. Okajimas Folia anat. jap. 46, 167.

Gezelius, K. \& FrIes, N. (1952) Phage resistant mutants induced in E. coli by caffeine. Hereditas, 38, 112.

Goldstein, A. \& Warren, R. (1962) Passage of caffeine into human gonadal and fetal tissue. Biochem. Pharmac. 11, 166.

GREeR, S. B. (1968) Growth inhibitors and their antagonists as mutagens and antimutagens in Escherichia. 7. gen. Microbiol. 18, 543.

KinLman, B. A. (1952) A survey of purine derivatives as inducers of chromosome changes. Hereditas, $38,115$.

Kinlman, B. A. \& Levan, A. (1949) The cytological effect of caffeine. Hereditas, 35, 109.

Kuhlmann, W., Fromme, H. G., Heege, E. M. \& Ostertag, W. (1968) The mutagenic action of caffeine in higher organisms. Cancer Res. 28, 2375.

LEE, S. (1971) Chromosome aberrations induced in cultured human cells by caffeine. Fap. F. Genet. 46, 337.

Leonard, A. (1970) Radiation-induced translocations in spermatogonia of mice. Mutat. Res. 11, 71.

Mrttler, S., Mittler, J. E. \& Owens, S. L. (1967) Loss of chromosomes and non-disjunction induced by caffeine in Drosophila. Nature, Lond. 214, 424.

Nishimura, H. \& NAKAI, K. (1960) Congenital malformations in offspring of mice treated with caffeine. Proc. Soc. exp. Biol. Med. 104, 140.

Norman, A., Sasaki, M. S., Ottoman, R. E. \& Fingerhut, A. C. (1966) Elimination of chromosome aberrations from human lymphocytes. Blood, 27, 705.

Novick, A. (1955) Mutagens and antimutagens. Brookhaven Symp. Biol. 8, 201.

Oster, I. I. (1958) The genetic basis of X-ray induced somatic damage. In: Proc. 2nd Australian Conf. on Radiation Biol., 1958, p. 268.

OstertaG, W. (1963) The genetic basis of somatic damage produced by radiation in third instar larvae of Drosophila melanogaster. I. Death before maturity. Z. VererbLehre, 94, 143. 
Ostertag, W. (1966a) Chemische Mutagenese an menschlichen Zellen in Kultur. Abh. math.-naturw. Kl. Akad. IViss. Mainz, $1,1$.

OstertaG, W. (1966b) Koffein-und Theophyllinmutagenese bein Zell- und Leukozytenkulturen des Menschen. Mutat. Res. 3, 249.

Ostertag, W., Duisberg, E. \& Stürmann, M. (1965) The mutagenic activity of caffeine in man. Mutat. Res. 2, 293.

Ostertag, W. \& Fromme, H.G. (1967) Morphologische und Chromosomale Veraenderungen an Leukozyten- und Hela-Zelkulturen des Menschen und Chromosomenverlust bei Drosophila melanogaster (9. Tagung der Deut. Gesellschaft Anthropol. Humangenetik 1965). Homo, 176186.

OstertaG, W. \& Greif, B. J. (1967) Die Erzeugung von Chromatidenbruechen durch Coffein in Leukocytenkulturen des Menschen. Humangenetik, 3, 282.

Ostertag, W. \& HAAKE, J. (1966) The mutagenicity in Drosophila melanogaster of caffeine and of other compounds which produce chromosome breakage in human cells in culture. Z. VererbLehre, 98, 299.

Ostertag, W. \& Muller, H. J. (1959) Genetic basis of somatic damage produced by radiation. Science, N.Y. 130, 1422.

SASAKI, M. S. \& Norman, A. (1967) Selection against chromosome aberrations in human lymphocytes. Nature, Lond. 214, 502.

WRAGG, J. B., GARR, J. V. \& Ross, V. (1967) Inhibition of DNA polymerase activity by caffeine in a mammalian cell line. 7. Cell Biol. 35, 146a.

ZetreRberg, G. (1959) The mutagenic effect of 8-ethoxycaffeine, caffeine and dimethylsulfate in the ophiostoma back-mutation test. Hereditas, 46, 279. 